\title{
Predictors of delirium after cardiac surgery delirium: Effect of beating-heart (off-pump) surgery
}

\author{
Jan Bucerius, MD \\ Jan F. Gummert, MD, PhD \\ Michael A. Borger, MD, PhD \\ Thomas Walther, MD, PhD \\ Nicolas Doll, MD \\ Volkmar Falk, MD, PhD \\ Dierk V. Schmitt, MD \\ Friedrich W. Mohr, MD, PhD
}

See related editorial on page 7.
From the Department of Cardiac Surgery, Heart Center, University of Leipzig, Leipzig, Germany.

Received for publication Dec 31, 2002; revisions requested Feb 20, 2003; revisions received June 10, 2003; accepted for publication July 14, 2003.

Address for reprints: Jan Bucerius, MD, University of Leipzig, Heart Center, Department of Cardiac Surgery, Strümpellstr. 39, D-04289 Leipzig, Germany (E-mail: bucerj@medizin.uni-leipzig.de).

J Thorac Cardiovasc Surg 2004;127:57-64 0022-5223/\$30.00

Copyright () 2004 by The American Association for Thoracic Surgery

doi:10.1016/S0022-5223(03)01281-9
Background: Despite improved outcomes after cardiac operations, postoperative delirium remains a common complication that is associated with increased morbidity and prolonged hospital stay.

Methods: Univariate and multivariate predictors of postoperative delirium were determined from prospectively gathered data on 16,184 patients undergoing cardiac operations with cardiopulmonary bypass (conventional, $n=14,342$ ) and without cardiopulmonary bypass (beating-heart surgery, $\mathrm{n}=1847$ ) between April 1996 and August 2001. Delirium was defined as a transient mental syndrome of acute onset characterized by global impairment of cognitive functions, a reduced level of consciousness, attentional abnormalities, increased or decreased psychomotor activity, and a disordered sleep-wake cycle.

Results: The overall prevalence of postoperative delirium was $8.4 \%$. Of 49 selected patient-related risk factors and treatment variables, 35 were highly associated with postoperative delirium by univariate analysis. Stepwise logistic regression revealed the following variables as independent predictors of delirium: history of cerebrovascular disease, peripheral vascular disease, atrial fibrillation, diabetes mellitus, left ventricular ejection fraction of $30 \%$ or less, preoperative cardiogenic shock, urgent operation, intraoperative hemofiltration, operation time of 3 hours or more, and a high perioperative transfusion requirement. Two variables were identified as having a significant protective effect against postoperative delirium: beating-heart surgery and younger patient age.

Conclusions: Postoperative delirium is a common complication in cardiac operations. The increased use of beating-heart surgery without cardiopulmonary bypass may lead to a lower prevalence of this complication and thus improve patient outcomes.

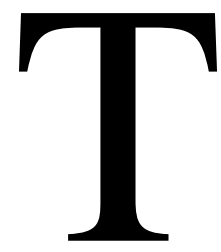

he number of cardiac operations is steadily increasing in industrialized countries. At the same time, the proportion of patients with elderly age and other risk factors for neurologic complications is also increasing. ${ }^{1}$ Neurologic complications after cardiac operations, including delirium, are associated with increased morbidity and mortality, as well as prolonged hospital stays. ${ }^{2}$

Neuropsychological and psychiatric disorders after cardiac operations have been well described since the 1950 s and continue to be a subject of active research. ${ }^{3}$ In contrast to relatively uncommon major neurologic complications, such as stroke, neuropsychological impairment is a common problem after cardiac operations; most 
studies report a prevalence of approximately $30 \%$. $^{2,4,5,6}$ However, the etiology and pathogenesis of cognitive impairment and delirium remain unknown. Many preoperative, intraoperative, and postoperative variables have been described as risk factors for these complications, but their exact etiologic roles have yet to be determined.

Many investigators have focused on the deleterious effects of cardiopulmonary bypass (CPB) on postoperative cognitive function. A recent development in cardiac surgery is the ability to perform operations, particularly coronary bypass surgery, without the use of CPB (so-called beatingheart $[\mathrm{BH}]$ surgery). Several studies have compared postoperative cognitive outcomes in patients undergoing $\mathrm{BH}$ surgery with those in patients undergoing conventional procedures with $\mathrm{CPB}$, but results have been inconclusive. ${ }^{7-13}$ Differences in the definition of neuropsychological impairment between studies may explain some of the discrepant results. $^{14}$

The purpose of this study was to identify risk factors for post-cardiac surgery delirium in a large number of patients from a single institution. In addition, we attempted to evaluate the effect of $\mathrm{BH}$ surgery without $\mathrm{CPB}$ on postoperative delirium.

\section{Methods}

\section{Study Population}

A total of 16,184 consecutive adult patients underwent heart operations between April 1996 and August 2001 at the Leipzig Heart Center. To assess the effects of $\mathrm{CPB}$ on postoperative delirium, patients were divided into groups on the basis of the type of operation performed. Coronary artery bypass grafting (CABG) with CPB was performed in 8917 patients (CABG-CPB). For the purposes of this study, patients undergoing coronary bypass grafting with CPB support, but without cardioplegic arrest, were still considered part of the CABG-CPB group. CABG without $\mathrm{CPB}$ $(\mathrm{BH})$, either through a median sternotomy $(\mathrm{n}=765)$ or through a left lateral minithoracotomy $(\mathrm{n}=1077)$, was performed in 1842 patients. Although most of these BH procedures were performed by 4 of our surgeons, all surgeons performed at least some of these operations. A third group of patients consisted of those undergoing cardiac valvular operations or combined CABG plus valvular operations $(\mathrm{n}=5425)$. Patients undergoing replacement of the ascending aorta $(\mathrm{n}=255)$ were also included in this group. All operations for this third group of patients were performed by using CPB and involved the opening of cardiac chambers (VALVE$\mathrm{CPB})$.

CPB was performed according to a standard protocol. The systemic body temperature was cooled to $32^{\circ} \mathrm{C}$, mean arterial pressure was kept $>60 \mathrm{~mm} \mathrm{Hg}$, and blood flow was maintained at $2.4 \mathrm{~L} \cdot \min -1 \cdot \mathrm{m}^{-2}$ body surface area during CPB. Proximal coronary bypass anastomoses were performed with a single aortic crossclamp technique (since 1999) in the CABG-CPB group and with a side-clamp technique in the $\mathrm{BH}$ group. Cardiotomy suction and administration of aprotinin were routinely used in all patients. We did not use coated oxygenators or tubing.

\section{Definition of Postoperative Delirium}

In accordance with the American Psychiatric Association guidelines, postoperative delirium was defined as a transient mental syndrome of acute onset characterized by global impairment of cognitive functions, a reduced level of consciousness, attentional abnormalities, increased or decreased psychomotor activity, and a disordered sleep-wake cycle. ${ }^{15,16}$ The diagnosis of delirium was made by physicians involved in the daily clinical care of patients and was most frequently made while patients were in the intensive care unit. Patients with prolonged delirium or focal neurologic signs underwent computed tomography of the brain to look for evidence of stroke. ${ }^{17}$ Stroke patients with delirium were included in the study cohort.

\section{Data Collection}

Perioperative data were recorded prospectively by using an online database system as previously described (Medwork database software; Lenz + Partner GmbH, Dortmund, Germany). ${ }^{18}$ All variables analyzed were entered by clinicians in a prospective fashion to accomplish a complete data set for each patient. Data quality was routinely assessed and verified by the generation of text documents that became the patient's chart during the hospital stay. Preoperative and intraoperative variables that were assessed as possible predictors of delirium are listed in Appendix 1. Postoperative variables were not analyzed as possible risk factors of delirium.

\section{Statistical Analysis}

Continuous variables are expressed as mean $\pm \mathrm{SD}$, and categorical data are expressed as proportions throughout the article. Comparisons of continuous variables between patients with and without postoperative delirium were performed with the Student unpaired $t$ test or analysis of variance, with the appropriate correction for multiple comparisons. Categorical variables were compared by $\chi^{2}$ analysis. Univariate analyses of risk factors for delirium were performed by calculating odds ratios (OR) with $95 \%$ confidence intervals. All $P$ values were 2 tailed. Variables with a $P$ value $<$ .05 were subjected to a multivariate logistic regression model to determine the risk-adjusted predictors of delirium by using a backward (Wald) stepwise procedure. A $P$ value of $<.05$ was used to enter and eliminate variables. ${ }^{19}$ All statistical analyses were performed with the SPSS statistical package version 9.0 (SPSS Inc, Chicago, Ill).

\section{Results}

Baseline preoperative patient characteristics for the different surgical groups are shown in Table 1. Patients older than 70 years constituted $32.5 \%$ of the population, and $3.6 \%$ were 80 years of age or older. Most patients were male, and $3.6 \%$ of the study population had a history of cerebrovascular disease.

Patients in the CABG-CPB group had a significantly higher age compared with both the $\mathrm{BH}$ and the VALVECPB groups $(P<.0001)$, and VALVE-CPB patients were significantly older than $\mathrm{BH}$ patients $(P<.0001)$. The preoperative left ventricular ejection fraction was lowest in the VALVE-CPB group $(P<.0001$ compared with the other 2 
TABLE 1. Preoperative patient characteristics for the different surgical groups

\begin{tabular}{|c|c|c|c|c|c|c|c|}
\hline Variable & No. & Age (y) & Sex, Male (\%) & LVEF (\%) & $\begin{array}{l}\text { CCS } \\
\geq 3\end{array}$ & $\begin{array}{c}\text { NYHA } \\
\geq \text { III }\end{array}$ & $\begin{array}{l}\text { No. of } \\
\text { grafts* }^{*}\end{array}$ \\
\hline Total & 16,184 & $64.8 \pm 10.4$ & $11,522(71.2 \%)$ & $52.0 \pm 22.0$ & $32.9 \%$ & $77.7 \%$ & $1.8 \pm 1.2$ \\
\hline CABG-CPB & 8917 & $65.4 \pm 9.2$ & $6887(77.2 \%)$ & $53.0 \pm 20.6$ & $36.0 \%$ & $79.9 \%$ & $2.5 \pm 0.8$ \\
\hline $\mathrm{BH}$ & 1842 & $63.1 \pm 10.6$ & $1402(76.1 \%)$ & $55.9 \pm 20.7$ & $39.6 \%$ & $71.4 \%$ & $1.3 \pm 0.6$ \\
\hline VALVE-CPB & 5425 & $64.6 \pm 12.0$ & $3233(59.6 \%)$ & $48.9 \pm 24.2$ & $25.5 \%$ & $76.2 \%$ & $0.8 \pm 1.2 \dagger$ \\
\hline
\end{tabular}

Continuous variables are expressed as mean $\pm \mathrm{SD}$.

$C A B G-C P B$, Coronary artery bypass grafting with cardiopulmonary bypass; $B H$, beating heart surgery; VALVE-CPB, valvular surgery with cardiopulmonary bypass with or without coronary artery bypass grafting; LVEF, left ventricular ejection fraction; NYHA, New York Heart Association heart failure classification; CCS, Canadian Cardiovascular Society angina classification.

*Coronary artery bypass grafts.

tCombined coronary bypass plus valvular or ascending aortic surgery.

groups). The left ventricular ejection fraction in the $\mathrm{BH}$ group was significantly higher than in the CABG-CPB group $(P<.0001)$. There were significantly more men in both coronary artery bypass groups compared with the VALVE-CPB group $(P<.0001)$.

Patients in the CABG-CPB group had a higher prevalence of Canadian Cardiovascular Society classification 3 or greater and received more coronary bypass grafts than patients in the $\mathrm{BH}$ group $(P<.0001$ and $P=.01$, respectively). The prevalence of New York Heart Association (NYHA) class III or greater symptomatology was highest in the CABG-CPB group $(P<.0001$ compared with the other groups) and was higher in the VALVE-CPB group than in the $\mathrm{BH}$ group $(P<.0001$; Table 1$)$.

The overall prevalence of postoperative delirium was $8.4 \%(\mathrm{n}=1354)$. Of these patients, $219(16.2 \%)$ also had a diagnosis of perioperative stroke. The prevalence of delirium varied among the 3 surgical groups as shown in Figure 1. Postoperative delirium was significantly $(P<.0001)$ less likely to occur in $\mathrm{BH}$ patients compared with the other 2 surgical groups. The prevalence of postoperative delirium in all patients $\geq 70$ years of age was $12.9 \%$, with significant differences among the 3 surgical groups (CABG-CPB, $11.9 \%$; BH, 5.1\%; VALVE-CPB, $16.4 \% ; P<.001$ ).

Patients with postoperative delirium were more prone to have postoperative respiratory insufficiency $(32.9 \%$ vs $7.0 \% ; P<.0001)$ and to require tracheal reintubation $(23.5 \%$ vs $5.1 \% ; P<.0001)$ than patients without delirium. In addition, patients with delirium had a significantly higher prevalence of sternum instability $(7.5 \%$ vs $1.9 \% ; P<$ .0001 ) and were more likely to require surgical revision of the sternal wound $(6.4 \%$ vs $1.4 \% ; P<.0001)$. Patients with delirium had a significantly longer intensive care stay (11.4 \pm 12.3 days vs $3.5 \pm 5.8$ days; $P<.0001$ ), which we defined as the length of time spent in the intensive care unit (with mechanical ventilation) plus the intermediate care unit (without mechanical ventilation). Furthermore, total postoperative hospitalization in patients with delirium was significantly longer compared with patients without delirium $(19.2 \pm 16.1$ days vs $11.0 \pm 8.3$ days; $P<.0001)$.
Univariate analysis revealed that 35 of 49 recorded preoperative and intraoperative variables had a significant association with postoperative delirium (Appendix 1, bold). Significant variables were consecutively subjected to a stepwise logistic regression analysis. Ten variables were identified as independent predictors of postoperative delirium, and 2 variables were associated with a significantly lower prevalence of delirium (Table 2). Of particular note was that operation without CPB had a protective effect against delirium in this risk-adjusted analysis. The prevalence of perioperative independent predictors of delirium and statistically significant differences regarding these predictors among the 3 groups are shown in Table 3 .

\section{Discussion}

This series was composed of more than 16,000 adults undergoing cardiac surgery, of whom $8.4 \%$ experienced postoperative delirium. All of the data were gathered in a prospective fashion by using an institutional software program that becomes the patient's medical chart while he or she is in the hospital.

The diagnosis of delirium is currently made with clinical assessment, ${ }^{15,16}$ in contrast to postoperative neuropsychological impairment, which is diagnosed with neuropsychological tests and usually is part of a research protocol. ${ }^{4,14,20}$ The definition of delirium chosen in this series is the same as that recommended by the American Psychiatric Association and is readily applicable by clinicians involved in the daily postoperative care of cardiac surgery patients. The symptoms of delirium-in particular, confusion-make neuropsychological testing impractical in this patient population. Postoperative delirium may represent a more severe form of neurologic injury than neuropsychological impairment, a complication that is known to be very common after cardiac surgery. ${ }^{4,7,14,20}$

The prevalence of postoperative delirium in our study varied among the different surgical procedures. Patients undergoing valve or combined valve and CABG operations had postoperative delirium more often than patients undergoing isolated CABG operations, a finding that has been 


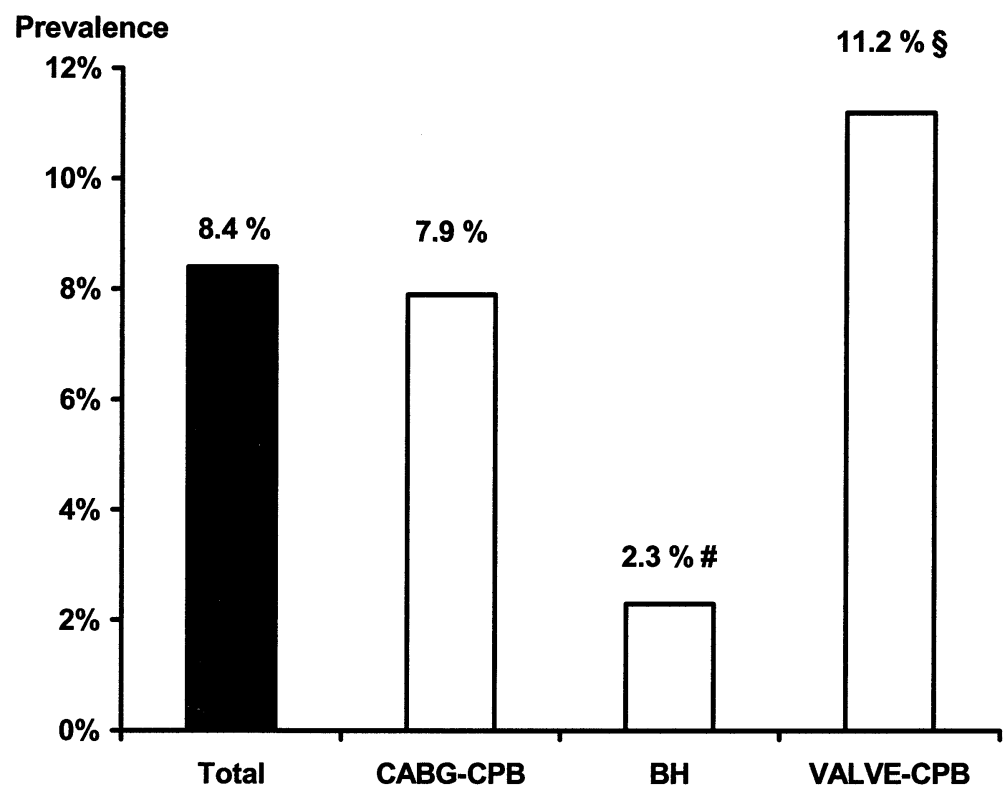

Figure 1. Prevalence of postoperative delirium according to the type of cardiac surgical procedure. $C A B G-C P B$, Coronary artery bypass grafting with cardiopulmonary bypass; $B H$, beating heart surgery; VALVE-CPB, valvular surgery with or without coronary artery bypass grafting with cardiopulmonary bypass. \#P 0001 versus CABG-CPB and VALVE-CPB. $\$ P<.0001$ versus CABG-CPB.

TABLE 2. Independent predictors of postoperative delirium analyzed by multivariate logistic regression analysis

\begin{tabular}{|c|c|c|c|}
\hline \multirow[b]{2}{*}{ Variable } & \multicolumn{3}{|c|}{$95 \%$} \\
\hline & $\begin{array}{l}\text { Odds } \\
\text { ratio }\end{array}$ & $\begin{array}{l}\text { Confidence } \\
\text { interval }\end{array}$ & $P$ value \\
\hline \multicolumn{4}{|c|}{ Variables associated with higher risk of delirium } \\
\hline $\begin{array}{l}\text { History of cerebrovascular } \\
\text { disease }\end{array}$ & 2.15 & $1.69-2.72$ & $<.0001$ \\
\hline Atrial fibrillation & 1.36 & $1.14-1.62$ & .0005 \\
\hline Diabetes mellitus & 1.31 & $1.16-1.49$ & $<.0001$ \\
\hline Peripheral vascular disease & 1.34 & $1.17-1.53$ & $<.0001$ \\
\hline LVEF $\leq 30 \%$ & 1.30 & $1.09-1.49$ & .0041 \\
\hline Preoperative cardiogenic shock & 1.23 & $1.05-1.45$ & .0122 \\
\hline Urgent operation & 1.17 & $1.02-1.34$ & .0245 \\
\hline Operating time $\geq 3 \mathrm{~h}$ & 1.26 & $1.01-1.45$ & .0009 \\
\hline Intraoperative hemofiltration & 1.26 & $1.06-1.49$ & .0079 \\
\hline $\mathrm{RBC}$ transfusion $\geq 2000 \mathrm{~mL}$ & 3.15 & $2.71-3.65$ & $<.0001$ \\
\hline \multicolumn{4}{|c|}{ Variables associated with lower risk of delirium } \\
\hline Beating-heart surgery & 0.47 & $0.32-0.69$ & .0001 \\
\hline \multicolumn{4}{|l|}{ Younger patient age } \\
\hline Age $<50$ y & 0.22 & $0.15-0.31$ & $<.0001$ \\
\hline Age $\geq 50$ and $<60$ y & 0.34 & $0.27-0.43$ & $<.0001$ \\
\hline Age $\geq 60$ and $<70 y$ & 0.6 & $0.52-0.68$ & $<.0001$ \\
\hline
\end{tabular}

$L V E F$, Left ventricular ejection fraction; $R B C$, red blood cells.

previously described. ${ }^{21}$ The reason for this observation is unknown but may be related to embolization of air that is trapped within cardiac chambers during VALVE procedures. $^{22}$
The cause of post-cardiac surgery delirium is unknown and is probably multifactorial in origin. ${ }^{15}$ Most patients with delirium have this complication shortly after awakening from anesthesia, ${ }^{23,24}$ and this suggests that intraoperative factors play a major role in the pathogenesis. It is for this reason that we did not include postoperative variables in our analysis of predictors of delirium.

A history of cerebrovascular disease was one of the strongest predictors of delirium in this series, with an OR of 2.15. The increased risk may be explained by the existence of atherosclerosis within the cerebrovascular system, particularly of the carotid arteries. ${ }^{4,25}$ Generalized atherosclerosis increases the risk of cerebral embolization, particularly during intraoperative aortic manipulation. ${ }^{26}$ The finding of diabetes (OR, 1.30) and peripheral vascular disease (OR, 1.34) as independent predictors of delirium may also be a result of their close association with atherosclerotic disease burden.

Previous investigators have observed an association between severity of underlying cardiac disease and postoperative delirium. Heller and associates ${ }^{27}$ described an increasing prevalence of postoperative delirium with increasing NYHA heart failure classification. Similarly, we found impaired left ventricular ejection fraction (OR, $1.23)$ and preoperative cardiogenic shock $(\mathrm{OR}, 1.24)$ to be independent predictors of delirium. Urgent surgery was also a predictor of delirium (OR, 1.16); this risk factor is a marker of the severity of underlying cardiac pathology. 
Preoperative history of atrial fibrillation was an independent predictor of postoperative delirium (OR, 1.35) in this study, possibly because of its widely recognized association with thromboembolization. Several previous investigators have described an association between cerebral embolization during cardiac operations and postoperative neurobehavioral deficits. ${ }^{20,26,28-30}$

Prolonged duration of surgery (OR, 1.29) and intraoperative hemofiltration $(\mathrm{OR}, 1.24)$ are indicators of increased operative complexity, a factor that has been previously shown to influence postoperative neurologic outcomes. ${ }^{5}$ In addition, prolonged operations involve longer $\mathrm{CPB}$ times, another risk factor for neurologic complications. ${ }^{2,25,31}$ The effect of prolonged anesthetic time on postoperative delirium is controversial; some investigators report a significant association, and others describe no correlation. ${ }^{32}$ It is interesting to note that a similar proportion of CABG-CPB and $\mathrm{BH}$ patients had a prolonged surgical procedure (Table 3 ), yet the prevalence of delirium was significantly lower in the $\mathrm{BH}$ group. Part of this difference may be related to the avoidance of $\mathrm{CPB}$ in the $\mathrm{BH}$ group.

A high transfusion requirement was a strong predictor of postoperative delirium $(\mathrm{OR}, 3.12)$. However, our database is unable to distinguish between intraoperative and postoperative transfusion administration. Increased transfusion requirement may have therefore partially reflected postoperative complications, making interpretation of this predictor difficult.

Advanced age is one of the most commonly reported independent predictors of postoperative delirium, ${ }^{25,33,34}$ probably because of its close association with the atherosclerotic disease process. Approximately one third of our patient population was older than 70 years of age, and our data confirmed that such patients are at increased risk for delirium (Table 2; Appendix 1).

The beneficial effect of BH surgery (OR, 0.14) on the prevalence of postoperative delirium in this series may be due to avoiding the deleterious effects of $\mathrm{CPB}$, as already stated. CPB may lead to a higher prevalence of postoperative delirium because of hypotensive periods during CPB and nonpulsatile blood flow. ${ }^{35}$ In addition, the risk of gaseous and particulate cerebral embolization, a widely recognized problem during $\mathrm{CPB}$, is avoided in $\mathrm{BH}$ surgery. ${ }^{7,20,28-30}$ Furthermore, the lower prevalence of delirium in the BH group may be explained by the avoidance of ascending aortic cannulation and the subsequent risk of atherosclerotic embolization. Indeed, aortic manipulation is avoided altogether in those $\mathrm{BH}$ patients who undergo minimally invasive direct CABG (MIDCAB).

Preoperative patient characteristics in the $\mathrm{BH}$ group revealed a younger mean age and higher left ventricular ejection fraction than in the CABG-CPB group. Furthermore, the number of CABGs was significantly lower than in
TABLE 3. Prevalence of independent predictors of postoperative delirium in relation to the different surgical procedures

\begin{tabular}{|c|c|c|c|c|}
\hline \multirow[b]{2}{*}{ Variable } & \multicolumn{4}{|c|}{ Prevalence (\%) } \\
\hline & \multicolumn{2}{|r|}{ CABG- } & BH & $\begin{array}{c}\text { VALVE } \\
\text { CPB }\end{array}$ \\
\hline \multicolumn{5}{|c|}{ Variables associated with higher risk of delirium* } \\
\hline $\begin{array}{l}\text { History of cerebrovascular } \\
\text { disease }\end{array}$ & 3.6 & 3.4 & 3.1 & 4.1 \\
\hline Atrial fibrillation & 9.1 & 4.2 & 3.3 & $19.1 \dagger$ \\
\hline Diabetes mellitus & 36.8 & $41.2 \ddagger$ & 29.4 & 27.8 \\
\hline Peripheral vascular disease & 20.0 & $21.8 \ddagger$ & $14.7 \S$ & 18.8 \\
\hline LVEF $\leq 30 \%$ & 9.2 & $8.3 \|$ & 6.1 & $11.7 \dagger$ \\
\hline Preoperative cardiogenic shock & 15.5 & 10.1 & 8.5 & $26.6 \dagger$ \\
\hline Urgent operation & 23.7 & 22.09 & 12.9 & $30.1 \dagger$ \\
\hline Operating time $\geq 3 \mathrm{~h}$ & 21.6 & 19.4 & 18.8 & $26.1 \dagger$ \\
\hline Intraoperative hemofiltration & 11.2 & 7.4 & $\mathrm{~N} / \mathrm{A}$ & $17.5 \#$ \\
\hline $\mathrm{RBC}$ transfusion $\geq 2000 \mathrm{~mL}$ & 10.3 & $8.8 \emptyset$ & 4.1 & $14.9+$ \\
\hline \multicolumn{5}{|c|}{ Variables associated with lower risk of delirium* } \\
\hline $\begin{array}{l}\text { Beating-heart surgery } \\
\text { Younger patient age }\end{array}$ & 11.4 & 01 & 100 & 0 \\
\hline Age $<50$ y & 8.8 & $6.3 \ddagger$ & 12.5 & 11.7 \\
\hline Age $\geq 50$ and $<60$ y & 16.6 & 17.1 & $20.6^{* *}$ & $14.4 \dagger$ \\
\hline Age $\geq 60$ and $<70 y$ & 38.3 & $40.4 \S$ & 37.9 & 34.9 \\
\hline
\end{tabular}

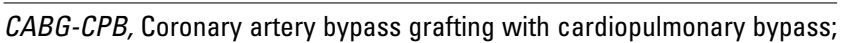
$B H$, beating heart surgery; VALVE-CPB, valvular surgery with cardiopulmonary bypass witih or without coronary artery bypass grafting; $L V E F$, left ventricular ejection fraction; $R B C$, red blood cells; $N / A$, not applicable.

${ }^{*}$ Analyzed by multivariate logistic regression analysis.

$\dagger P<.0001$ vs CABG-CPB and BH.

$\ddagger P<.0001$ vs BH and VALVE-CPB

$\S P<.0001$ vs VALVE-CPB.

$\| P=.001$ vs $\mathrm{BH}$.

$\Uparrow P<.0001$ vs $\mathrm{BH}$.

$\# P<.0001$ vs CABG-CPB.

${ }^{*} P=.002$ vs CABG-CPB.

the CABG-CPB group. This finding was expected, however, given that the $\mathrm{BH}$ group was composed of patients who underwent both off-pump CABG for 1 or more bypass grafts and minimally invasive direct CABG for single bypass grafting (that is, left internal thoracic artery to the left anterior descending coronary artery). In addition, the prevalence of severe clinical symptoms (NYHA classification of III or higher and Canadian Cardiovascular Society classification $\geq 3$ ) was significantly higher in the CABG-CPB group compared with the $\mathrm{BH}$ group.

This study has several limitations. Because of the retrospective design of our study and the lack of randomization, selection bias may have accounted for some of the observed differences in delirium among surgical groups. That is, lower-risk patients may have been selected to undergo BH surgery. The possibility of selection bias, as for all nonrandomized studies, is the main limitation of our study. However, it is important to note that the $\mathrm{BH}$ group did not have the lowest prevalence of 
all independent predictors of delirium (Table 3). In addition, multivariate logistic regression analysis revealed that $\mathrm{BH}$ surgery was associated with a lower risk of delirium, even after other risk factors were accounted for. We therefore believe that BH surgery, with subsequent avoidance of CPB and minimization of aortic manipulation, may lead to a lower risk of postoperative delirium. Recently published series comparing postoperative neurocognitive outcome in patients undergoing on- and offpump coronary bypass operations have confirmed our findings of better results with off-pump CABG. ${ }^{11-13}$

Another limitation of this study is the fact that the clinicians who were responsible for making the diagnosis of delirium were not blinded to surgical group status. However, a very large number of clinicians were involved in the diagnosis of delirium, and most had no vested interest in the outcome of our study. Another limitation is that the large number of clinicians involved in our study increases the chance that the diagnosis of delirium was not always consistent from patient to patient. However, the large number of clinicians also increases the generalizability of our findings. Furthermore, independent neurologists were often consulted to confirm the diagnosis of delirium. We therefore believe that our results are relatively unbiased, generalizable, and valid.

\section{Conclusions}

Postoperative delirium is a common complication after cardiac surgical procedures. Since delirium and other neurologic complications are associated with increased morbidity and resource utilization, it is important to identify their independent predictors. BH surgery without CPB seems to be associated with a decreased risk of postoperative delirium and should be considered as one of the strategies for minimizing cerebral injury during cardiac operations.

\section{References}

1. Warner CD, Weintraub WS, Craver JM, Jones EL, Gott JP, Guyton RA. Effect of cardiac surgery patient characteristics on patient outcomes from 1981 through 1995. Circulation. 1997;96:1575-9.

2. Roach GW, Kanchuger M, Mangano CM, Newman M, Nussmeier N, Wolman R, et al. Adverse cerebral outcomes after coronary bypass surgery. Multicenter Study of Perioperative Ischemia Research Group and the Ischemia Research and Education Foundation Investigators. N Engl J Med. 1996;335:1857-63.

3. Fox HM, Rizzo ND, Gifford S. Psychological observations of patients undergoing mitral surgery—a study of stress. Am Heart J. 1954;48: 645-70.

4. Newman MF, Kirchner JL, Phillips-Bute B, Gaver V, Grocott H, Jones $\mathrm{RH}$, et al. Longitudinal assessment of neurocognitive function after cardiac surgery: perioperative decline predicts long-term (5-year) neurocognitive deterioration. $N$ Engl J Med. 2001;344:395-402.

5. Smith LW, Dimsdale JE. Postcardiotomy delirium: conclusion after 25 years? Am J Psychiatry. 1989;146:452-8.

6. Harrison MJG. The potential role of carotid artery disease. In: Smith PL, Taylor KM, editors. Cardiac surgery and the brain. London: Edward Arnold; 1993. p. 17-23.
7. Murkin JM, Boyd WD, Ganapathy S, Adams SJ, Peterson RC. Beating heart surgery: why expect less central nervous system morbidity? Ann Thorac Surg. 1999;68:1498-501.

8. Arom KV, Flavin TF, Emery RW, Kshettry VR, Janey PA, Petersen RJ. Safety and efficacy of off-pump coronary artery bypass grafting. Ann Thorac Surg. 2000;69:704-10.

9. Iaco AL, Contini M, Teodori G, Di Mauro M, Di Giammarco G, Vitolla G, et al. Off or on bypass: what is the safety threshold? Ann Thorac Surg. 1999;68:1486-9.

10. Taggart DP, Browne SM, Halligan PW, Wade DT. Is cardiopulmonary bypass still the cause of cognitive dysfunction after cardiac operations? J Thorac Cardiovasc Surg. 1999;118:414-20.

11. Stroobant N, Van Nooten G, Belleghem Y, Vingerhoets G. Short-term and long-term neurocognitive outcome in on-pump versus off-pump CABG. Eur J Cardiothorac Surg. 2002;22:559-64.

12. Van Dijk D, Jansen EWL, Hijman R, Nierich AP, Diephuis JC, Moons $\mathrm{KG}$, et al. Cognitive outcome after off-pump and on-pump coronary artery bypass graft surgery: a randomized trial. JAMA. 2002;287:140512.

13. Zamvar V, Williams D, Hall J, Payne N, Cann C, Young K, et al. Assessment of neurocognitive impairment after off-pump and onpump techniques for coronary artery bypass graft surgery: prospective randomised controlled trial. BMJ. 2002;325:1268-72.

14. Blumenthal JA, Mahanna EP, Madden DJ, White WD, Croughwell ND, Newman MF. Methodological issues in the assessment of neuropsychologic function after cardiac surgery. Ann Thorac Surg. 1995; 59:1345-50.

15. Lipowski ZJ. Delirium: acute confusional states. Oxford: Oxford University Press; 1990.

16. Diagnostic and statistical manual of mental disorders. 3rd ed, rev. Washington (DC): American Psychiatric Association; 1987.

17. Edmunds LH Jr, Clark RE, Cohn LE, Grunkemeier GL, Miller DC, Weisel RD. Guidelines for reporting morbidity and mortality after cardiac valvular operations. J Thorac Cardiovasc Surg. 1996;112:708-11.

18. Gummert JF, Kluge M, Reissmann EM, Bung J, Mohr FW. Einführung eines komplexen medizinischen Dokumentationssystems am Herzzentrum Leipzig. In: Krian A, Scheld HH, editors. Dokumentationsverfahren in der Herzchirurgie III. Darmstadt: Steinkopff; 1998. p. $99-103$

19. Rosner BA. Fundamentals of biostatistics. 4th ed. Belmont (CA): Duxbury Press; 1995.

20. Hammon JW Jr, Stump DA, Kon ND, Cordell AR, Hudspeth AS, Oaks TE, et al. Risk factors and solutions for the development of neurobehavioral changes after coronary artery bypass grafting. Ann Thorac Surg. 1997;63:1613-8.

21. Walzer TA, Herrmann M, Wallesch CW, Starkstein SE, Herrmann M. Neuropsychological disorders following coronary bypass surgery. J Neurol Neurosurg Psychiatry. 1997;63:644-8.

22. Murkin JM. Neurologic dysfunction after CAB or valvular surgery: is the medium the miscreant? Anesth Analg. 1993;76:222-7.

23. Herrmann M, Ebert AD, Galazky I, Wunderlich MT, Kunz WS, Huth C. Neurobehavioral outcome prediction after cardiac surgery. Role of neurobiochemical markers of damage to neuronal and glial brain tissue. Stroke. 2000;31:645-50.

24. van der Mast RC, Roest FH. Delirium after cardiac surgery: a critical review. J Psychosom Res. 1996;41:13-30.

25. Tuman KJ, McCarthy RJ, Najafi H, Ivankovich AD. Differential effects of advanced age on neurologic and cardiac risks of coronary artery operations. J Thorac Cardiovasc Surg. 1992;104:1510-7.

26. Borger MA, Peniston CM, Weisel RD, Vasiliou M, Green REA,Feindel CM. Neuropsychologic impairment after coronary bypass surgery: effect of gaseous microemboli during perfusionist interventions. J Thorac Cardiovasc Surg. 2001;121:743-9.

27. Heller SS, Frank KA, Malm JR, Bowman JFO, Harris PD, Charlton $\mathrm{MH}$, et al. Psychiatric complications of open-heart surgery-a reexamination. $N$ Engl J Med. 1970;283:1015-20.

28. Pugsley W, Klinger L, Paschalis C, Treasure T, Harrison M, Newman $\mathrm{S}$. The impact of microemboli during cardiopulmonary bypass on neuropsychological functioning. Stroke. 1994;25:1393-9.

29. Stump DA, Rogers AT, Hammon JW, Newman SP, Phil D. Cerebral 
emboli and cognitive outcome after cardiac surgery. J Cardiothorac Anesth. 1996;10:1-8.

30. Clark RE, Brillman J, Davis DA, Lovell MR, Price TR, Magovern GJ. Microemboli during coronary artery bypass grafting: genesis and effect on outcome. J Thorac Cardiovasc Surg. 1995;109:249-57.

31. Brown WR, Moody DM, Challa VR, Stump DA, Hammon J. Longer duration of cardiopulmonary bypass is associated with greater number of cerebral microemboli. Stroke. 2000;31:707-13.

32. van der Mast RC. Postoperative delirium. Dement Geriatr Cogn Disord. 1999;10:401-5.
33. Newman MF, Croughwell ND, Blumenthal JA, White WD, Lewis JB, Smith LR, et al. Effect of aging on cerebral autoregulation during cardiopulmonary bypass: association with postoperative cognitive dysfunction. Circulation. 1994;90(5 Pt 2):II243-9.

34. van der Mast RC, van den Broek WW, Fekkes D, Pepplinkhuizen L, Habbema JDF. Incidence and preoperative predictors for delirium after cardiac surgery. J Psychosom Res. 1999;46:479-83.

35. Taylor KM. Cardiac surgery and the brain: an introduction. In: Smith PL, Taylor KM, editors. Cardiac surgery and the brain. London: Edward Arnold; 1992. p. 1-14.

APPENDIX 1. Perioperative variables analyzed by univariate analysis: factors that had a statistically significant association with delirium are printed in bold

\begin{tabular}{|c|c|c|c|}
\hline \multirow[b]{2}{*}{ Variable } & \multicolumn{2}{|c|}{ Prevalence, \% (n) } & \multirow[b]{2}{*}{$P$ value } \\
\hline & $\begin{array}{l}\text { Patients with } \\
\text { delirium } \\
(n=1354)\end{array}$ & $\begin{array}{c}\text { Patients without } \\
\text { delirium } \\
(n=14,830)\end{array}$ & \\
\hline \multicolumn{4}{|l|}{ Preoperative variables } \\
\hline \multicolumn{4}{|l|}{ Age } \\
\hline Age $<\mathbf{5 0}$ years & $2.7 \%(37)$ & $9.4 \%(1392)$ & $<.0001$ \\
\hline Age $\geq 50<60$ years & $7.6 \%(103)$ & $17.5 \%(2589)$ & $<.0001$ \\
\hline Age $\geq 60<70$ years & $33.9 \%(459)$ & $38.7 \%(5746)$ & $<.0001$ \\
\hline Age $\geq 70<80$ years & $48.9 \%(663)$ & $30.9 \%(4595)$ & $<.0001$ \\
\hline Age $\geq \mathbf{8 0}$ years & $6.8 \%(92)$ & $3.4 \%(508)$ & $<.0001$ \\
\hline Sex (Male) & $73.4 \%(994)$ & $71.0 \%(10,528)$ & .06 \\
\hline History of syncope & $12.3 \%$ (167) & $9.7 \%$ (1444) & .002 \\
\hline History of embolism & $4.7 \%(64)$ & $3.1 \%(455)$ & .002 \\
\hline History of cardiogenic shock & $21.0 \%(285)$ & $10.9 \%(1622)$ & $<.0001$ \\
\hline $\begin{array}{l}\text { Diabetes mellitus (glucose intolerance treated with diet, oral hypoglycemics, or } \\
\text { insulin) }\end{array}$ & $42.5 \%(576)$ & $32.5 \%(4817)$ & $<.0001$ \\
\hline Hyperlipidemia & $43.2 \%(585)$ & $46.5 \%(6901)$ & .021 \\
\hline Arterial hypertension (patient taking antihypertensive medication before surgery) & $70.7 \%(957)$ & $67.5 \%(10,017)$ & .017 \\
\hline $\begin{array}{l}\text { History of renal disease (history of renal failure or pathologic increased serum } \\
\text { creatinine treated medically without hemofiltration and/or dialysis) }\end{array}$ & $8.6 \%(117)$ & $3.9 \%(588)$ & $<.0001$ \\
\hline Dialysis-dependent renal insufficiency & $0.7 \%(10)$ & $0.7 \%(103)$ & .864 \\
\hline Preoperative infection (infectious disease, including endocarditis) & $3.6 \%(49)$ & $1.9 \%(290)$ & $<.0001$ \\
\hline History of cerebrovascular disease (including stroke, TIA, and PRIND) & $8.5 \%(115)$ & $3.2 \%(474)$ & $<.0001$ \\
\hline NYHA $\geq$ III & $81.7 \%(1106)$ & $77.3 \%(11,465)$ & $<.0001$ \\
\hline LVEF $\leq \mathbf{3 0} \%$ (assessed by angiography or 2-dimensional echocardiography) & $14.5 \%(196)$ & $8.7 \%(1295)$ & $<.0001$ \\
\hline History of peripheral vascular disease & $29.4 \%(398)$ & $19.1 \%(2831)$ & $<.0001$ \\
\hline Atrial fibrillation (history of preoperative atrial fibrillation) & $15.8 \%(214)$ & $8.5 \%(1259)$ & $<.0001$ \\
\hline Urgent operation & $35.0 \%(474)$ & $22.6 \%(3358)$ & $<.0001$ \\
\hline History of pulmonary disease (chronic pathologic pulmonary function test) & $9.2 \%(124)$ & $6.7 \%(995)$ & .001 \\
\hline Prior myocardial infarction & $43.3 \%(586)$ & $42.4 \%(6290)$ & .565 \\
\hline $\begin{array}{l}\text { Emergency surgery (emergency surgery due to complications during coronary } \\
\text { angiography and/or PTCA) }\end{array}$ & $0.9 \%(12)$ & $0.6 \%(89)$ & .204 \\
\hline $\operatorname{CCS} \geq 3$ & $34.4 \%(466)$ & $32.8 \%(4861)$ & .227 \\
\hline Prior cardiac surgery & $6.3 \%(85)$ & $5.3 \%(784)$ & .13 \\
\hline Prior CABG & $3.8 \%(52)$ & $3.3 \%(482)$ & .234 \\
\hline Prior surgery for aortic aneurysm & $0.1 \%(2)$ & $0.3 \%(50)$ & .319 \\
\hline Prior aortic valve surgery & $0.7 \%(9)$ & $1.0 \%(153)$ & .252 \\
\hline Prior mitral valve surgery & $1.5 \%(20)$ & $0.9 \%(144)$ & .087 \\
\hline \multicolumn{4}{|l|}{ Intraoperative variables } \\
\hline Duration of surgery $\geq 3 \mathrm{~h}$ & $29.3 \%(397)$ & $20.9 \%(3094)$ & $<.0001$ \\
\hline
\end{tabular}




\begin{tabular}{|c|c|c|c|}
\hline \multirow[b]{2}{*}{ Variable } & \multicolumn{2}{|c|}{ Prevalence, \% (n) } & \multirow[b]{2}{*}{$P$ value } \\
\hline & $\begin{array}{c}\text { Patients with } \\
\text { delirium } \\
\text { (n }=1354)\end{array}$ & $\begin{array}{c}\text { Patients without } \\
\text { delirium } \\
(n=14,830)\end{array}$ & \\
\hline Total CPB time $\geq 2 \mathrm{~h}$ & $21.9 \%(297)$ & $12.6 \%(1875)$ & $<.0001$ \\
\hline Ischemic time $\geq 1 \mathrm{~h}$ & $30.4 \%(411)$ & $21.3 \%(3163)$ & $<.0001$ \\
\hline Intraoperative hemofiltration & $16.9 \%(229)$ & $9.5 \%(1409)$ & $<.0001$ \\
\hline Intraoperative hypothermia $<32^{\circ} \mathrm{C}$ & $46.9 \%(635)$ & $36.4 \%(5405)$ & $<.0001$ \\
\hline Intraoperative $\mathrm{RBC}$ transfusion $\geq 1000 \mathrm{~mL}$ & $6.1 \%(83)$ & $2.5 \%(377)$ & $<.0001$ \\
\hline Intraoperative low cardiac output & $3.6 \%(49)$ & $2.1 \%(3011)$ & .001 \\
\hline Intraoperative IABP & $3.0 \%(41)$ & $1.9 \%(280)$ & .006 \\
\hline Intraoperative need for pacemaker stimulation & $28.9 \%(392)$ & $20.0 \%(2972)$ & $<.0001$ \\
\hline Use of cardioplegia & $81.5 \%(1103)$ & $77.1 \%(11,435)$ & $<.0001$ \\
\hline BH & $3.2 \%(43)$ & $12.1 \%(1799)$ & $<.0001$ \\
\hline OPCAB & $2.4 \%(32)$ & $4.9 \%(733)$ & $<.0001$ \\
\hline MIDCAB & $0.8 \%(11)$ & $7.2 \%(1066)$ & $<.0001$ \\
\hline CABG-CPB & $52.4 \%(706)$ & $57.1 \%(8211)$ & .024 \\
\hline VALVE-CPB & $44.7 \%(605)$ & $32.5 \%(4820)$ & $<.0001$ \\
\hline Valve surgery & $44.6 \%(604)$ & $32.5 \%(4821)$ & $<.0001$ \\
\hline $\begin{array}{l}\text { Combined surgery (CABG and valvular surgery, ascending aortic surgery, and/or } \\
\text { other procedures) }\end{array}$ & $25 \%(338)$ & $14.6 \%(2168)$ & $<.0001$ \\
\hline Double valve surgery & $3.9 \%(53)$ & $2.2 \%(328)$ & $<.0001$ \\
\hline $\mathrm{OPCAB}$ - conversion to $\mathrm{CABG}$ with cardiopulmonary bypass & $0.07 \%(1)$ & $0.2 \%(30)$ & .513 \\
\hline Aortic valve and/or ascending aortic surgery & $12.0 \%(163)$ & $11.2 \%(1667)$ & .37 \\
\hline Mitral valve surgery & $3.8 \%(51)$ & $4.4 \%(657)$ & .714 \\
\hline Intraoperative blood loss $\geq 500 \mathrm{~mL}$ & $1.0 \%(14)$ & $0.6 \%(88)$ & .069 \\
\hline \multicolumn{4}{|l|}{ Perioperative variables } \\
\hline Perioperative RBC transfusion $\geq 2000 \mathrm{~mL}$ & $30.4 \%(411)$ & $8.5 \%(1254)$ & $<.0001$ \\
\hline
\end{tabular}

$C A B G-C P B$, Coronary artery bypass grafting with cardiopulmonary bypass; $B H$, beating heart surgery; VALVE-CPB, valvular with cardiopulmonary bypass with or without coronary artery bypass grafting; $C A B G$, coronary artery bypass grafting; $O P C A B$, off-pump coronary artery bypass grafting; MIDCAB, minimally invasive direct coronary artery bypass grafting; $R B C$, red blood cells; $L V E F$, left ventricular ejection fraction; $P T C A$, percutaneous transcoronary angioplasty; $C P B$, cardiopulmonary bypass; IABP, intra-aortic balloon pump; TIA, transient ischemic attack; PRIND, prolonged reversible ischemic neurologic deficit; NYHA, New York Heart Association heart failure classification; CCS, Canadian Cardiovascular Society angina classification.

\section{Online-www.aats.org}

Now you can get The Journal of Thoracic and Cardiovascular Surgery online. The Journal online brings you faster delivery time, easy searching of current and back issues, links to PubMed, AATS, WTSA, and other important sites, and more. Visit the Journal online today.

\section{Receive tables of contents by e-mail}

To receive the tables of contents by e-mail, sign up through our Web site at http://www.mosby.com/jtcvs

Choose E-mail Notification

Simply type your e-mail address in the box and click the Subscribe button.

Alternatively, you may send an e-mail message to majordomo@mosby.com.

Leave the subject line blank and type the following as the body of your message: subscribe jtcvs_toc

You will receive an e-mail to confirm that you have been added to the mailing list.

Note that TOC e-mails will be sent out when a new issue is posted to the Web site. 